\title{
Cell wall protein mannosylation determines Candida albicans cell surface hydrophobicity
}

\author{
James Masuoka and Kevin C. Hazen \\ Author for correspondence: Kevin C. Hazen. Tel: +1 804924 8067. Fax : +1 8049248060. \\ e-mail: khazen@Virginia.edu
}

Department of Pathology, University of Virginia Medical Center Box 214, Charlottesville, VA 22908, USA

\begin{abstract}
Cell surface hydrophobicity (CSH) has been shown to be an important factor in the ability of the opportunistic pathogenic yeast Candida albicans to adhere to surfaces. Hydrophobic cells adhere more readily to host tissue, and are more resistant to phagocytic killing, than hydrophilic cells. Consequently, CSH plays an important role in the pathogenicity of $\mathrm{C}$. albicans. Previous work suggested a relationship between CSH and cell wall protein glycosylation. The present work tests the hypothesis that changes in outer chain mannosylation, rather than complete loss of oligosaccharide groups, are sufficient to modulate CSH. These studies compared wild-type cells to a variant that has altered mannosylation and is hydrophobic under conditions in which wild-type cells are hydrophilic. Composition analysis of cell surface digests showed that the glycosylation of wild-type cell surface proteins was much more extensive than that seen in the variant. Antibodies which recognize the acid-labile and acidstable portions of $\mathrm{C}$. albicans mannan showed not only differences between wild-type and variant cells but also differences between wild-type hydrophilic and wild-type hydrophobic cells. The results suggest that exposure of surface hydrophobic regions on $C$. albicans may be related to the abundance of phosphodiester-linked, acid-labile mannosyl groups rather than the complete loss of outer chain mannosylation on cell wall proteins.
\end{abstract}

Keywords: hydrophobicity, adhesion, cell wall, Candida albicans, mannosylation

\section{INTRODUCTION}

Adherence to surfaces is an important first step in microbial colonization of new environments. Adherence is thus a key event in the pathogenesis of medically important micro-organisms, including the moulds and yeasts. Recent epidemiological reports demonstrating a substantial increase in bloodstream infections caused by fungi emphasize the importance of understanding the attachment mechanism in pathogenesis (Beck-Sagué et al., 1993; Sternberg, 1994).

As in filamentous fungi, expression of cell surface hydrophobicity $(\mathrm{CSH})$ by the opportunistic pathogenic yeast Candida albicans influences several important processes affecting disease development. These processes ultimately determine virulence and include adhesion to tissues and plastics, morphogenesis and resistance to phagocytosis (Glee et al., 1995; Hazen, 1989; Hazen et

Abbreviations: A9-wt, wild-type of C. albicans strain A9; A9-Vx, variant $x$ of $C$. albicans strain A9; $\mathrm{CSH}$, cell surface hydrophobicity; CTAB, cetyltrimethylammonium bromide. al., 1991; Antley \& Hazen, 1988). Previous studies of the C. albicans cell wall suggested a relationship between $\mathrm{CSH}$ and cell wall mannoproteins. Tokunaga and other workers observed fibrils on C. albicans surfaces by use of scanning and transmission electron microscopy techniques and concluded that these fibrils were the outer glycoprotein layer, mainly mannoprotein (Tokunaga et al., 1986; Cassone, 1989; Shepherd, 1987). Subsequent freeze-fracture electron microscopy studies showed hydrophilic cells have long, well ordered, regularly radiating fibrils (Hazen \& Hazen, 1992). The fibrils on hydrophobic cells are shorter, blunt, aggregated and variable, with areas of relatively dense, somewhat radiating fibrils, and other areas of sparse, folded fibrils. Hazen et al. (1990) reported that treatment of hydrophilic cells with tunicamycin, which inhibits $\mathrm{N}$ linked glycosylation, caused the cells to become hydrophobic. Freeze-fracture photographs of tunicamycintreated cells show short, aggregated fibrils similar to those observed on hydrophobic cells (Hazen $\&$ Hazen, 1992). These results supported the hypothesis that increased hydrophobicity, and thus increased adherence, was linked to decreases in surface protein glycosylation. 
The global inhibition of $\mathrm{N}$-linked glycosylation by tunicamycin precludes its use in studies designed to understand the effects of partial glycosylation on CSH. Using a strategy of serial enrichment, Whelan et al. (1990) produced a set of variants of C. albicans wildtype strain A9 (A9-wt). These variants (designated A9V1 to A9-V10) were shown to have various alterations in outer chain mannosylation, with reduction of the $1 \rightarrow$ $\left.\mathrm{PO}_{4}\right)-\alpha$ - and $(1 \rightarrow 6)-\alpha$-linkages being common to all (Whelan et al., 1990). We have used one of these variants (A9-V10) to see if changes in outer chain mannosylation are sufficient to affect $\mathrm{CSH}$, or if complete loss of the $\mathrm{N}$-linked glycosyl groups is required.

\section{METHODS}

Cell culture. C. albicans A9-wt and variant (A9-V1 to A9-V10) cells were provided by Professor Richard Calderone, Georgetown University, Washington, DC, USA. Cultures were maintained as frozen stocks. Yeast cells from frozen stocks were subcultured three times at $24 \mathrm{~h}$ intervals in yeast nitrogen base buffered with $0.055 \mathrm{M}$ sodium phosphate $\mathrm{pH} 7.2$ and supplemented with $2 \%(\mathrm{w} / \mathrm{v})$ glucose. Prior to use in experiments, the cells were harvested by centrifugation and washed three times with cold, sterile distilled water. For the purposes of this study, an apparently contiguous unit or microcolony of blastoconidia is defined as a cell. Buds and mother cells are each designated a sphere. This operational definition was used because of the high level of aggregation exhibited by the A9-V10 cells, which would otherwise lead to an artificially low cell concentration.

Growth temperature was used as a convenient, in vitro method for controlling $\mathrm{CSH}$. Wild-type cells grown at $23^{\circ} \mathrm{C}$ are hydrophobic at stationary phase $(26 \mathrm{~h}$ incubation period). Those grown at $37^{\circ} \mathrm{C}$ are hydrophilic at stationary phase (Hazen \& Hazen, 1987a).

Monoclonal antibodies. mAb $6 \mathrm{C} 5$ is an IgG2a class monoclonal antibody which was generated at the University of Virginia, VA, USA and recognizes the C. albicans hydrophobic wall protein designated CAgp38. mAb B6.1 and mAb B6 are IgM monoclonal antibodies, produced at Montana State University, MT, USA, which recognize distinct and separate portions of $C$. albicans mannan (Fig. 1). mAb B6.1 recognizes a 1,2- $\beta$-mannotriose group in the acid-labile portion (Fig. 1, C; Han \& Cutler, 1995; Y. Han and others, unpublished results). $\mathrm{mAb} \mathrm{B} 6$ recognizes an oligosaccharide group in the acid-stable region (Fig. 1, B; Y. Han \& J. E. Cutler, unpublished results).

Cell surface hydrophobicity. This was measured by the hydrophobic microsphere assay developed in our laboratory (Hazen \& Hazen, 1987b). Microsphere attachment was assessed by bright field microscopy at $\times 400$ magnification. The percentage of cells with three or more attached microspheres was recorded as the percentage hydrophobicity.

Electron microscopy. A9-wt and A9-V10 cells were prepared for freeze-fracture electron microscopy as previously described (Hazen \& Hazen, 1992). This method of preparation, with no prefixation or cryoprotectant, minimized the distortion of cell wall features (Hazen \& Hazen, 1992; Kusamichi et al., 1990).

Preparation of cell surface mannoprotein. A9-wt and A9-V10 cell walls were subjected to limited enzymic digestion to release the surface wall components (Glee et al., 1995). A modification of the published method was that the $1,3-\beta$ glucanase (Lyticase, Sigma) was added to the suspension to a concentration of $250 \mathrm{U} \mathrm{ml}^{-1}$. Another was that the digestion

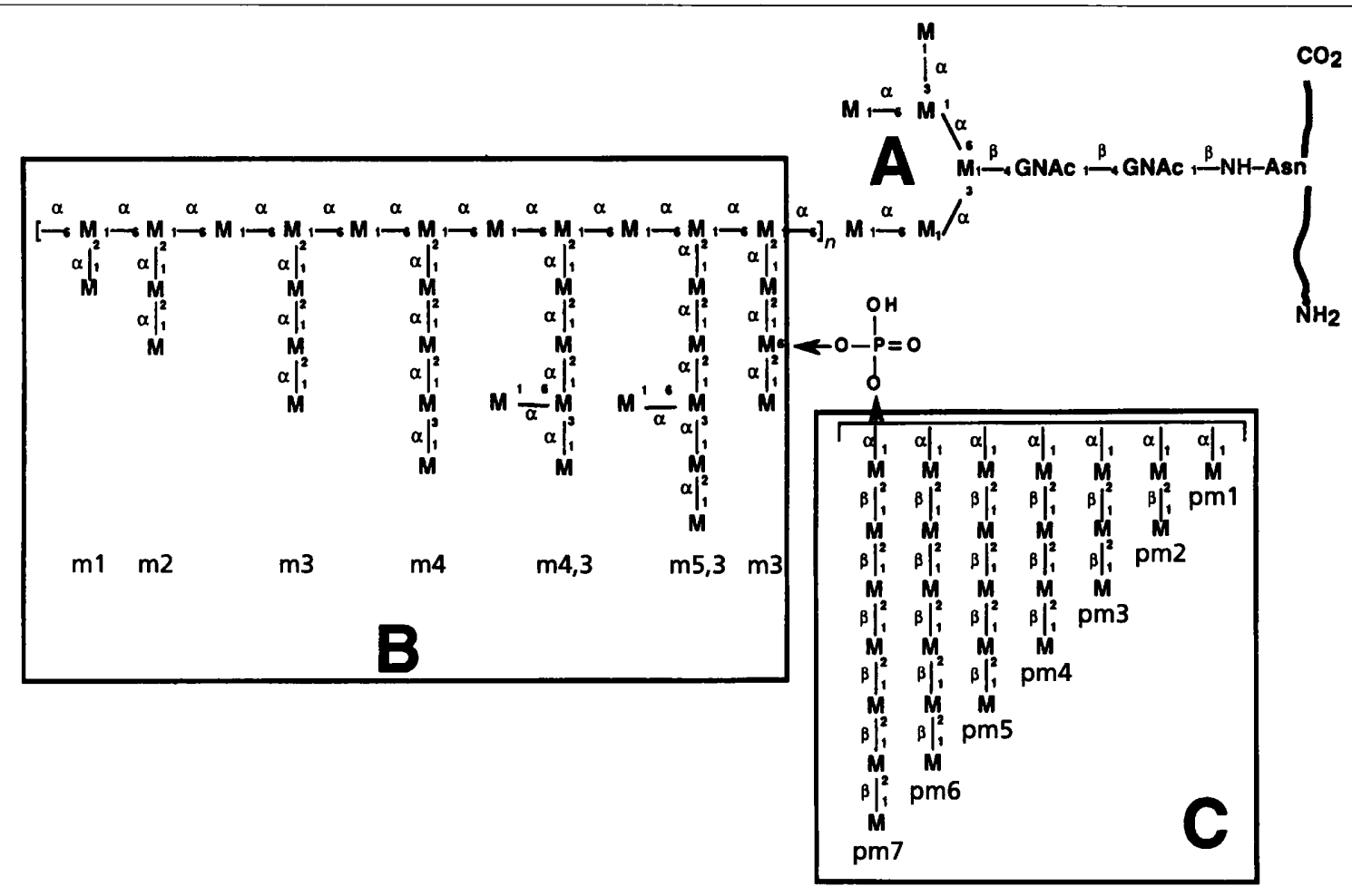

Fig. 1. Proposed structure of the mannan component of $C$. albicans phosphomannoproteins based on that of Shibata et al. (1995). $\mathrm{M}$ and GNAc represent mannose and $\mathrm{N}$-acetylglucosamine, respectively. The sequence of the side branches within the bracketed repeat unit is not specified. 
was carried out until the concentration of released protein reached approximately $300 \mu \mathrm{g} \mathrm{ml}^{-1}$. Protein release was monitored by the Coomassie Plus assay (Pierce). By releasing primarily the surface wall components, this limited enzymic digestion consequently minimized cytoplasmic contaminants. Evidence for the limited scope of this digestion was the lack of ghost cells present at the end of the digestion period (not shown).

Mannans were extracted from wall digests using cetyltrimethylammonium bromide (CTAB) based on the method described by Okubo et al. (1981). Five millilitres $8 \%$ (w/v) $C T A B$ stock solution was slowly added to $10 \mathrm{ml}$ digest supernatant fluid. The mannan-CTAB complex was allowed to form during a $2 \mathrm{~h}$ incubation at room temperature. The pellet was separated by centrifugation at $3000 \mathrm{~g}$ for $10 \mathrm{~min}$ and washed with $5 \mathrm{ml}$ distilled water. The wash was added to the supernatant fluid. The mannan-CTAB complex was then precipitated by adding $10 \mathrm{ml} 1 \%(\mathrm{w} / \mathrm{v})$ boric acid and adjusting the $\mathrm{pH}$ to 8.8 with $2 \mathrm{M} \mathrm{NaOH}$. The precipitate was allowed to settle for $1 \mathrm{~h}$ at room temperature and pelleted by centrifugation at $3000 \mathrm{~g}$ for $10 \mathrm{~min}$. The borate pellet, containing the mannan fraction, was washed twice with $0.5 \%$ sodium acetate $\mathrm{pH} 8.8$ and suspended in $2 \mathrm{ml}$ PBS $(0.15 \mathrm{M}$ sodium chloride, $0.01 \mathrm{M}$ sodium phosphate) for carbohydrate and protein determination. The remaining supernatant fluid, which contained the glucan fraction, was reserved for carbohydrate and protein analysis.

Protein electrophoresis. Cell wall proteins from surface digests were separated by SDS-PAGE using the discontinuous buffer system of Laemmli (1970) as modified by Hames (1990) with one exception. EDTA $(0 \cdot 2 \mathrm{M})$ was substituted for SDS in resolving and stacking gel recipes (Hazen et al., 1990). Gels were loaded with $25 \mu \mathrm{g}$ total protein in each lane. The separated proteins were then transferred to nitrocellulose membranes (Transblot, Bio-Rad) (Towbin et al., 1979).

Western blotting. Strips were cut from the membranes, rehydrated in distilled water and soaked in Dulbecco's PBS $\mathrm{pH} 7 \cdot 2$. Strips were blocked by incubation at $37^{\circ} \mathrm{C}$ for $1 \mathrm{~h}$ in Dulbecco's PBS containing $5 \%(\mathrm{w} / \mathrm{v})$ dry nonfat milk and $0.2 \%$ Tween 20 . This solution was also used for all antibody dilutions and wash steps. Blocked strips were incubated for $1-2 \mathrm{~h}$ at $37^{\circ} \mathrm{C}$ in primary antibody solution. mAb $6 \mathrm{C} 5$ was used at a 1:2500 dilution of ascites. $\mathrm{mAb} B 6.1$ and $\mathrm{mAb}$ B6 were prepared in serum-free medium and used as a 1:500 dilution of the concentrated culture filtrate $\left(7 \mu \mathrm{g} \mathrm{ml}^{-1}\right.$ final concentration). A mixture of irrelevant mouse $\operatorname{IgM}(1: 5000)$ and $\operatorname{IgG}(1: 1000)$ was used as a control (Sigma). Strips were washed three times (10 min each) and incubated for $1 \mathrm{~h}$ at $37^{\circ} \mathrm{C}$ in secondary antibody solution (a mixture of alkalinephosphatase-conjugated goat anti-mouse IgG (1:30000) (Sigma) and alkaline-phosphatase-conjugated rabbit antimouse IgM (1:1000) (Zymed Laboratories). Following treatment with secondary antibody, the strips were washed three times (15 min each) with $0.1 \mathrm{M}$ Tris $\mathrm{pH} 9.5,0.1 \mathrm{M} \mathrm{NaCl}$, $1 \mathrm{mM} \mathrm{MgCl}$. Reactive proteins were visualized with nitro blue tetrazolium and 5-bromo-4-chloro-3-indoyl phosphate (Savage et al., 1992).

Biochemical assays. Hexose content was determined by the phenol-sulfuric acid method of Dubois et al. (1956). Sample absorbances (Gilford spectrophotometer, model 260) were compared to a mannose standard curve. Protein concentration was determined by the bicinchoninic acid assay (BCA, Pierce) (Smith et al., 1985). BSA was used to generate a standard curve. Protein and hexose values were normalized to $\mu \mathrm{g}$ per $10^{9}$ spheres.
Statistical methods. Comparisons of protein and hexose content were carried out using analysis of variance. Pair-wise comparisons used the Bonferroni correction to minimize inappropriate conclusions of significance (Hassard, 1991). Significance was determined at the $P=0.05$ level.

\section{RESULTS}

\section{Cell surface hydrophobicity and ultrastructure}

The CSH of A9-wt cells was typical of other wild-type strains. Cells grown to stationary phase at $23^{\circ} \mathrm{C}$ were hydrophobic $\left(\mathrm{CSH}>95 \%\right.$ ) while those grown at $37^{\circ} \mathrm{C}$ were hydrophilic $(\mathrm{CSH}<5 \%)$. Among the variants, A9-V10 was the most strikingly different from the wildtype. These cells are extremely hydrophobic under conditions in which A9-wt cells are hydrophilic (CSH $>99 \%$ at both growth temperatures). Because of this dramatic difference, A9-V10 was chosen for further study as a comparison with the wild-type. It was reasoned that, if our hypothesis is correct, this large change in CSH status should accompany the largest, and most easily discernible, change in cell wall protein mannosylation among the variants.

Freeze-fracture electron microscopy of A9-wt and A9V10 cells grown at $37^{\circ} \mathrm{C}$ (Fig. 2) supported the evidence linking CSH and the mannoprotein fibrils. A9-wt cells
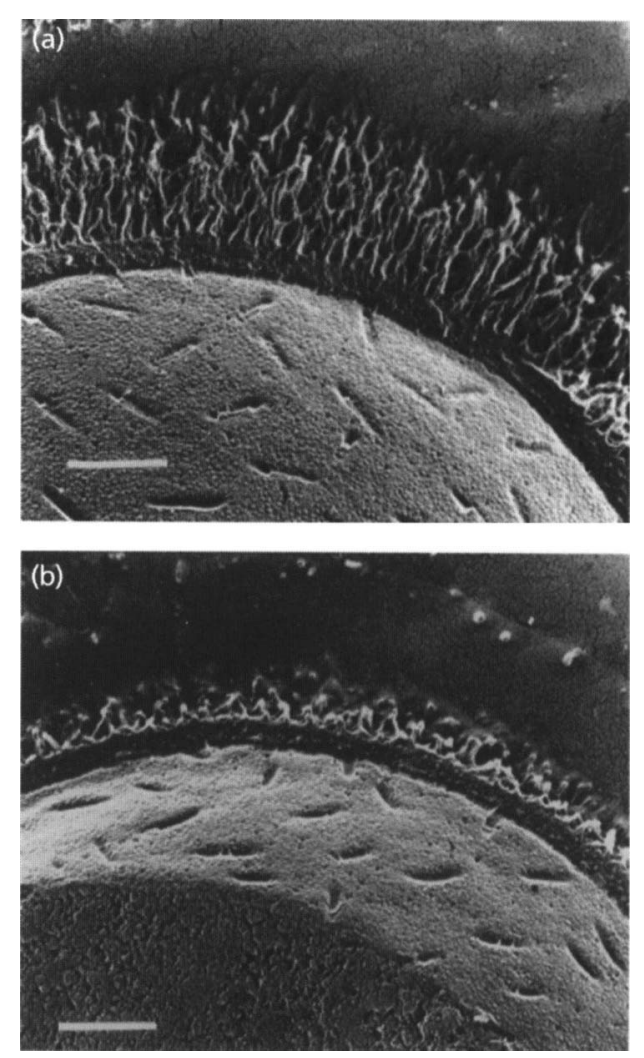

Fig. 2. Freeze-fracture, freeze-etched $A 9-w t$ (a) and A9-V10 (b) cells grown at $37^{\circ} \mathrm{C}$. Representative cells are shown. Fibrils visible on A9-wt cells are typical for hydrophilic cells. Fibrils visible on A9-V10 cells are shorter and more compact than those on A9-wt hydrophobic cells. Bar, $277 \mathrm{~nm}$. 
Table 1. Composition of cell wall digests and fractions from A9-wt and A9-V10 cells grown at $37^{\circ} \mathrm{C}$ and $23^{\circ} \mathrm{C}$

Data are expressed as $\mu \mathrm{g}$ per $10^{9}$ spheres. Values represent the arithmetic mean \pm sample standard deviation $(n)$. Within each row, values followed by the same superscript letters are significantly different at the $P=0.05$ level.

\begin{tabular}{|c|c|c|c|c|}
\hline & \multicolumn{2}{|c|}{ A9-wt } & \multicolumn{2}{|c|}{ A9-V10 } \\
\hline & $\begin{array}{c}37^{\circ} \mathrm{C} \\
\text { (hydrophilic) }\end{array}$ & $\begin{array}{c}23^{\circ} \mathrm{C} \\
\text { (hydrophobic) }\end{array}$ & $\begin{array}{c}37^{\circ} \mathrm{C} \\
\text { (hydrophobic) }\end{array}$ & $\begin{array}{c}23^{\circ} \mathrm{C} \\
\text { (hydrophobic) }\end{array}$ \\
\hline \multicolumn{5}{|l|}{ Digest } \\
\hline Protein & $425 \cdot 1 \pm 62(8)$ & $326 \cdot 5 \pm 70(8)$ & $358 \cdot 9 \pm 55(4)$ & $357 \cdot 6 \pm 95(4)$ \\
\hline Hexose & $1220 \cdot 8^{a b c} \pm 155(8)$ & $839 \cdot 4^{a} \pm 197(8)$ & $764^{b} \pm 143$ & $638 \cdot 1^{c} \pm 142(4)$ \\
\hline \multicolumn{5}{|c|}{ Mannan fraction } \\
\hline Protein & $10 \cdot 6 \pm 5(6)$ & $13 \cdot 2 \pm 7(6)$ & $10 \cdot 9(2)$ & $8.4(1)$ \\
\hline Hexose & $205 \cdot 6 \pm 74(6)$ & $231 \cdot 6 \pm 104(6)$ & $57 \cdot 3(2)$ & $13 \cdot 4(1)$ \\
\hline \multicolumn{5}{|c|}{ Glucan fraction } \\
\hline Protein & $466 \cdot 8^{d} \pm 72(6)$ & $307 \cdot 0^{a} \pm 82(6)$ & $452 \cdot 4 \pm 78(3)$ & $355 \cdot 9 \pm 94(3)$ \\
\hline Hexose & $651 \cdot 8^{e} \pm 55(6)$ & $409 \cdot 0^{e f} \pm 136(6)$ & $677 \cdot 8^{f} \pm 95(3)$ & $467 \cdot 0 \pm 158(3)$ \\
\hline
\end{tabular}

possessed an outer layer composed of long, compact and evenly distributed fibrils, 200-250 nm in length, and similar to other wild-type strains (Fig. 2a) (Hazen \& Hazen, 1992). In contrast, the fibrils on the surface of $37^{\circ} \mathrm{C}$-grown A9-V10 cells were much shorter and clustered (Fig. 2b). These fibrils were approximately $50 \mathrm{~nm}$ in length, which is shorter than those observed on hydrophobic A9-wt cells and germ tubes (85 nm) (Hazen \& Hazen, 1992).

\section{Composition analysis of cell surface digests}

Composition analysis of A9-wt and A9-V10 cell surface digests was carried out to compare A9-wt and A9-V10 mannosylation in more detail, and to examine the extent of the A9-V10 mannosylation defect (Table 1). Enzymic digestion of yeast cell walls released similar amounts of protein from the surface of all four cell sets. Digests of hydrophilic wild-type cells, however, contained significantly higher amounts of neutral hexose than those from either hydrophobic wild-type or variant cells. Among the hydrophobic cells, the hexose content did not differ significantly. These results supported the freeze-fracture studies indicating altered surface protein glycosylation in the A9-V10 cells (Fig. 2).

To determine how much of the difference in carbohydrate content seen in the digests was due to mannose specifically, the mannoproteins were separated from the cell surface digests using CTAB. The mannan fraction of hydrophilic and hydrophobic wild-type cells contained similar amounts of protein (Table 1 ). The protein content of A9-V10 mannan, from cells grown at either temperature, was roughly equivalent to wild-type. However, the precipitation of mannan from A9-V10 digests was variable. Only two of three trials on variant cells grown at $37^{\circ} \mathrm{C}$, and only one of three trials of variant cells grown at $23^{\circ} \mathrm{C}$, produced any discernible pellet. The reason for this may be the glycosylation level of the proteins in this fraction, as is discussed below. The mannan fractions from A9-wt cells contained similar amounts of hexose regardless of their hydrophobicity status (Table 1), suggesting that it is not necessary for yeast cells to lose completely the mannan component to become hydrophobic. This conclusion is consistent with the freeze-fracture photographs which show that the mannoprotein fibrils on hydrophobic wild-type cells are shortened, rather than absent (Hazen \& Hazen, 1992).

There was an approximately $72 \%$ reduction in the hexose content of the mannan fraction of $37^{\circ} \mathrm{C}$-grown A9-V10 cells relative to that of hydrophilic wild-type cells (Table 1 ). When $23{ }^{\circ} \mathrm{C}$-grown A9-V10 cells were compared to hydrophilic A9-wt cells, this reduction was approximately $93 \%$. The carbohydrate content of A9V10 mannan was also compared to wild-type using carbohydrate: protein ratios. These were 5.3 and 1.6 for A9-V10 cells grown at $37^{\circ} \mathrm{C}$ and $23^{\circ} \mathrm{C}$, respectively. For wild-type cells, the ratios were 19.4 and 17.5 , respectively. Since A9-wt and A9-V10 mannan fractions contained similar amounts of protein, these ratios suggested that it is a change in the extent of protein mannosylation, rather than an overall loss of mannoprotein, which accounts for the difference between A9-wt and A9-V10 mannan.

The decreased glycosylation of A9-V10 mannoproteins may itself explain the difficulty in producing a mannan pellet from these digests. Since the method used here was originally designed for the separation of neutral polysaccharides (Barker et al., 1957), it is possible that CTAB requires interaction with moderate to long oligosaccharide chains to successfully form a complex, although the specifics of the interaction are not known. 


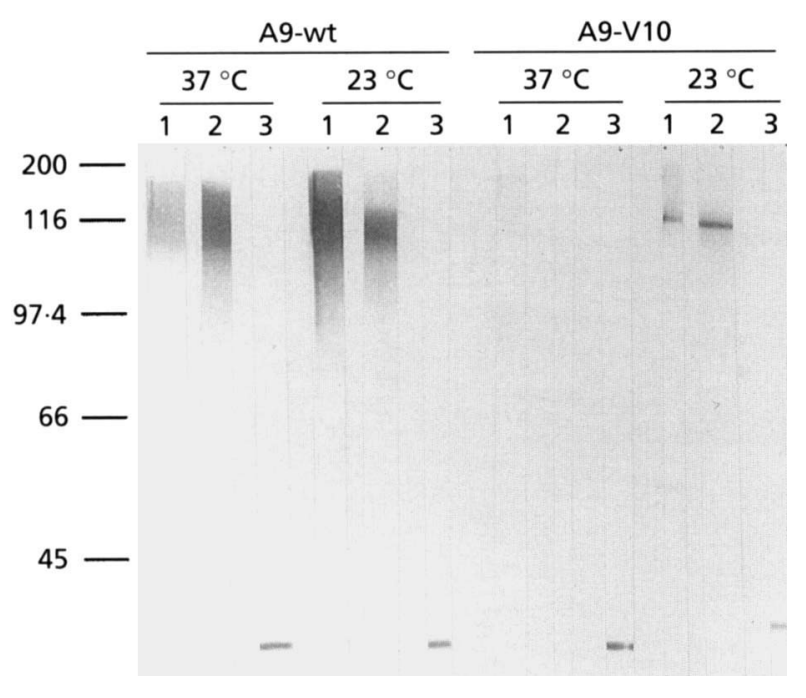

Fig. 3. Representative immunoblot of separated wall proteins from A9-wt and A9-V10 cells grown at $37^{\circ} \mathrm{C}$ and $23^{\circ} \mathrm{C}(n=3)$. Lanes: 1, mAb B6; 2, mAb B6.1; 3, mAb 6C5. No signal was observed in control lanes containing either irrelevant $\operatorname{lgG} / \mathrm{lgM}$ plus secondary antibody or secondary antibody alone (not shown). Molecular mass markers are given to the left only to serve as a guide.

The glucan fraction composition of the four cell sets more closely reflected that seen in the original digests, taking into account the greater amount of carbohydrate separated in the wild-type mannan fractions (Table 1). Also, the composition of this fraction appeared to relate to growth temperature rather than cell type. The similarity of glucan content between wild-type and variant cells indicated that the A9-V10 cells possess no defect in glucan synthesis as compared to the wild-type.

\section{Western blotting}

mAbs specific for various portions of the mannoproteins provided a way to characterize the difference between A9-wt and A9-V10 surface protein mannosylation in greater detail and possibly identify a difference between hydrophilic and hydrophobic wild-type cells. The mAbs were used to probe Western blots of surface wall proteins (Fig. 3). The interaction of $\mathrm{mAb} \mathrm{B} 6$ or $\mathrm{mAb}$ B6.1 (Fig. 3, lanes 1 and 2) with cell wall proteins from $23^{\circ} \mathrm{C}$-grown A9-V10 cells resulted in a single, discrete band. Neither antibody visibly bound to any protein from $37^{\circ} \mathrm{C}$-grown A9-V10 cell walls. These staining patterns indicated a severe reduction or total absence of the $\mathrm{mAb}$ B6 and mAb B6.1 epitopes on the A9-V10 cell surface. They further suggested a lack of complexity in A9-V10 cell surface protein glycosylation. As was seen in the wild-type cells, glycoprotein staining typically results in a smear due to microheterogeneity caused by slight differences in glycosylation (Hilborn \& Anastassiadis, 1971).

Both mAb B6 and mAb B6.1 bound to a wide molecular mass range $(100-180 \mathrm{kDa})$ of A9-wt cell wall proteins. However, mAb B6.1 recognized a wider molecular mass range of mannoproteins from hydrophilic $\left(37^{\circ} \mathrm{C}\right.$-grown) A9-wt cells as compared to hydrophobic $\left(23^{\circ} \mathrm{C}\right.$-grown) A9-wt cells. Conversely, the reactivity of $\mathrm{mAb}$ B6 was greater in hydrophobic cells (Fig. 3).

A hydrophobic C. albicans cell wall protein, CAgp38, was present at similar levels in all four cell sets (Fig. 3, lane 3). Although it appears in this comparison that the mobility of this protein is shifted in the A9-V10 cells grown at $23^{\circ} \mathrm{C}$, this is a result of the four samples being electrophoresed separately. Careful measurement of the individual blots indicated that the apparent molecular mass of CAgp38 was constant. Non-specific protein staining by Amido Black showed that the cell proteins as a whole did not differ among the four samples (not shown). The latter two results supported the composition analysis suggesting that the change in mannosylation was not due to an overall decrease in protein.

\section{DISCUSSION}

The results presented here demonstrate a direct correlation between $\mathrm{CSH}$ and the level of cell surface protein mannosylation, rather than glycosylation as a whole. They further suggest a specific biochemical model for a point at which CSH may be regulated by changes in the phosphomannosyl groups.

This model is explained using the C. albicans phosphomannoprotein structure proposed by Shibata et al. (1995) (Fig. 1). In this structural representation, the bracketed group of side branches represents a segment of outer chain mannosylation. In wild-type Saccharomyces cerevisiae cells, $n$ has been reported to be as high as 10 (Herscovics \& Orlean, 1993). The side branches within the brackets (m1-m5,3 and pm1-pm7) are representatives of each distinct oligomannoside found. The molar ratios of the side branches differ. Thus, a given side branch, including the phosphomannosyl groups, may occur more than once in a segment. Finally, the exact sequence of the side branches is not specified. It is possible that the side branches could occur at any position within the segment or, in fact, anywhere along the 1,6- $\alpha$-chain.

Based on this structural model, wall proteins from hydrophilic A9-wt cells have undergone extensive elongation of the outer mannose chains and branches (i.e. A, B and C are present, Fig. 1). This elongation results in highly glycosylated mannoproteins (Table 1). Epitopes for both mAb B6.1 and B6 are present. The presence of the acid-labile oligomannosyl mAb B6.1 epitopes throughout the mannosylated region may reduce the observed binding by $\mathrm{mAb} \mathrm{B} 6$ (Fig. 3).

When hydrophilic A9-wt cells become hydrophobic, they lack some or most of the phosphodiester-linked, acid-labile branches (leaving A and B, Fig. 1). Lack of these branches, whilst not resulting in gross changes to the mannoprotein glycosylation levels (Table 1), does affect the antibody detection pattern. Reactivity to $\mathrm{mAb}$ B6.1 is decreased, resulting in increased reactivity to mAb B6 (Fig. 3) and apparently increased CSH.

A9-V10 cells represent an extreme case of hydro- 
phobicity. These cells may not be able to extend protein glycosylation much beyond the core group (leaving a mannosyl group similar to A, Fig. 1). This results in severe reductions in mannoprotein glycosylation (Table 1). Also, surface digests from these cells show little or no reactivity to $\mathrm{mAb} \mathrm{B} 6.1$ or $\mathrm{mAb} \mathrm{B} 6$, yet maintain overall protein levels as well as reactivity to antibodies against the hydrophobic proteins (Fig. 3). It is also apparent that the mannosylation defect of A9-V10 is more extreme than necessary to make wild-type cells hydrophobic. It may be that A9-V10 represents the C. albicans homologue of the S. cerevisiae mnn9 mutant (Ballou, 1982).

It is not yet clear which subset of wall proteins vary in their glycosylation between hydrophilic and hydrophobic cells. One possibility is that the proteins responsible for the hydrophobic phenotype are themselves regulated in terms of their glycosylation. However, if this were the case, the apparent molecular masses of the mannoproteins detected by $\mathrm{mAb}$ B6 and mAb B6.1 would be expected to be different between hydrophilic and hydrophobic cells. Since this was not observed, this theory is unlikely. Another possibility is that a separate set of proteins provides a carbohydrate umbrella which can mask the hydrophobic proteins.

Although virulence was not specifically tested here, these results fit within the context of previous observations regarding C. albicans pathogenesis. Hydrophobic cells, in possessing fewer phosphomannan linkages, present fewer epitopes to which an immunoprotective response can be elicited (Domer et al., 1989). They also, consequently, lack the 1,2- $\beta$-mannotetraose groups which are recognized by certain macrophages ( $\mathrm{Li} \&$ Cutler, 1993) and may be less likely to be phagocytosed by a mannose-receptor-mediated process. In addition, hydrophobic $C$. albicans cells that are phagocytosed have been shown to be more resistant to killing (Antley \& Hazen, 1988). Finally, loss of the mannan cover exposes the hydrophobic wall proteins which allows the cells to more readily bind to and invade host tissue.

The comparative analysis of A9-wt and A9-V10 cell walls supports a model that describes a mechanism by which CSH status is affected by subtle changes in cell wall protein mannosylation. This model, which states that reduction of the phosphodiester-linked 1,2- $\beta$-oligomannosyl tertiary branches (Fig. 1), rather than loss of entire $N$-linked glycan groups, is sufficient to increase cell $\mathrm{CSH}$, is a refinement over the previous one based on tunicamycin experiments (Hazen et al., 1990). Phosphate-linked cell wall polysaccharides also play a role in the virulence of bacteria, such as the mycobacteria (McNeil et al., 1990). Thus, the addition of phosphomannose may be a key, pathogen-specific step to be targeted in the development of future therapeutic interventions for selected mycoses.

\section{ACKNOWLEDGEMENTS}

We thank Margaretta Allietta for her work in producing the freeze-fracture transmission electron micrographs, and Dr Pati Glee and the University of Virginia Hybridoma Facility for their work in producing the $6 \mathrm{C} 5 \mathrm{mAb}$. We thank Drs Yongmoon Han, Toshio Kanbe, Robert Cherniak and J. E. Cutler for the use, production and epitope determination of $\mathrm{mAb}$ B6.1 and mAb B6. We thank Dr Doris M. Haverstick for her suggestions and criticisms during the preparation of this manuscript. This work was supported in part by PHS grants R29AI31048 and RO1AI31048 (K.C.H.), and F32AI09428 (J.M.) from the National Institute of Allergy and Infectious Diseases.

\section{REFERENCES}

Antley, P. P. \& Hazen, K. C. (1988). Role of yeast cell growth temperature on Candida albicans virulence in mice. Infect Immun 56, 2884-2890.

Ballou, C. E. (1982). Yeast cell wall and cell surface. In The Molecular Biology of the Yeast Saccharomyces: Metabolism and Gene Expression, pp. 335-360. Edited by J. N. Strathern, E. W. Jones \& J. R. Broach. Cold Spring Harbor, NY: Cold Spring Harbor Laboratory.

Barker, S. A., Stacey, M. \& Zweifel, G. (1957). The separation of neutral polysaccharides. Chem Ind 11, 330.

Beck-Sagué, C. M., Jarvis, W. R. \& National Nosocomial Infections Surveillance System (1993). Secular trends in the epidemiology of nosocomial fungal infections in the United States, 1980-1990. $J$ Infect Dis 167, 1247-1251.

Cassone, A. (1989). Cell wall of Candida albicans: its function and its impact on the host. Curr Top Med Mycol 3, 248-314.

Domer, J. E., Garner, R. E. \& Befidi-Mengue, R. N. (1989). Mannan as an antigen in cell-mediated immunity (CMI) assays and as a modulator of mannan-specific CMI. Infect Immun 57, 693-700.

Dubois, M., Gilles, K. A., Hamilton, J. K., Rebers, P. A. \& Smith, F. (1956). Colorimetric method for determination of sugars and related substances. Anal Chem 28, 350-356.

Glee, P. M., Sundstrom, P. \& Hazen, K. C. (1995). Expression of surface hydrophobic proteins by Candida albicans in vivo. Infect Immun 63, 1373-1379.

Hames, B. D. (1990). One-dimensional polyacrylamide gel electrophoresis. In Gel Electrophoresis of Proteins, pp. 1-147. Edited by B. D. Hames \& D. Rickwood. Oxford University Press: Oxford.

Han, Y. \& Cutler, J. E. (1995). Antibody response that protects against disseminated candidiasis. Infect Immun 63, 2714-2719.

Hassard, T. H. (1991). Understanding Biostatistics. St Louis, MO: Mosby Year Book.

Hazen, K. C. (1989). Participation of yeast cell surface hydrophobicity in adherence of Candida albicans to human epithelial cells. Infect Immun 57, 1894-1900.

Hazen, K. C. \& Hazen, B. W. (1987a). Temperature-modulated physiological characteristics of Candida albicans. Microbiol Immunol 31, 497-508.

Hazen, K. C. \& Hazen, B. W. (1987b). A polystyrene microsphere assay for detecting cell surface hydrophobicity within Candida albicans populations. J Microbiol Methods 6, 289-299.

Hazen, K. C. \& Hazen, B. W. (1992). Hydrophobic surface protein masking by the opportunistic fungal pathogen Candida albicans. Infect Immun 60, 1499-1508.

Hazen, K. C., Lay, J.-G., Hazen, B. W., Fu, R. C. \& Murthy, S. (1990). Partial biochemical characterization of cell surface hydrophobicity and hydrophilicity of Candida albicans. Infect Immun 58, 3469-3476. 
Hazen, K. C., Brawner, D. L., Riesselman, M. H., Jutila, M. A. \& Cutler, J. E. (1991). Differential adherence of hydrophobic and hydrophilic Candida albicans yeast cells to mouse tissues. Infect Immun 59, 907-912.

Herscovics, A. \& Orlean, P. (1993). Glycoprotein biosynthesis in yeast. FASEB J 7, 540-550.

Hilborn, J. C. \& Anastassiadis, P. A. (1971). Estimation of the molecular weights of acidic mucopolysaccharides by polyacrylamide gel electrophoresis. Anal Biochem 39, 88-92.

Kusamichi, M., Monodane, T., Tokunaga, M. \& Koike, H. (1990). Influence of surrounding media on preservation of cell wall ultrastructure of Candida albicans revealed by low temperature scanning electron microscopy. J Electron Microsc 39, 477-486.

Laemmli, U. K. (1970). Cleavage of structural proteins during the assembly of the head of bacteriophage T4. Nature 227, 680-685.

Li, R.-K. \& Cutler, J. E. (1993). Chemical definition of an epitope/adhesion molecule on Candida albicans. J Biol Chem 268, 18293-18299.

McNeil, M., Daffe, M. \& Brennan, P. J. (1990). Evidence for the nature of the link between the arabinogalactan and peptidoglycan of mycobacterial cell walls. J Biol Chem 265, 18200-18206.

Okubo, Y., Shibata, N., Ichikawa, T., Chaki, S. \& Suzuki, S. (1981). Immunochemical study on bakers' yeast mannan prepared by fractional precipitation with cetylmethylammonium bromide. Arch Biochem Biophys 212, 204-215.

Savage, D., Mattson, G., Desai, S., Nielander, G., Morgensen, S. \&
Conklin, E. (1992). Avidin-Biotin Chemistry: a Handbook. Rockford, IL: Pierce Chemical Co.

Shepherd, M. G. (1987). Cell envelope of Candida albicans. Crit Rev Microbiol 15, 7-25.

Shibata, N., Ikuta, K., Imai, T. \& 7 other authors (1995). Existence of branched side chains in the cell wall mannan of pathogenic yeast, Candida albicans. J Biol Chem 270, 1113-1122.

Smith, P. K., Krohn, R. I., Hermanson, G. T. \& 7 other authors (1985). Measurement of protein using bicinchoninic acid. Anal Biochem 150, 76-85.

Sternberg, S. (1994). The emerging fungal threat. Science 266, 1632-1634.

Tokunaga, M., Kusamichi, M. \& Koike, H. (1986). Ultrastructure of outermost layer of cell wall in Candida albicans observed by rapid-freezing technique. J Electron Microsc 35, 237-246.

Towbin, H., Staehelin, T. \& Gordon, J. (1979). Electrophoretic transfer of proteins from polyacrylamide gels to nitrocellulose sheets : procedure and some applications. Proc Natl Acad Sci USA 76, 4350-4354.

Whelan, W. L., Delga, J. M., Wadsworth, E., Walsh, T. J., KwonChung, K. J., Calderone, R. \& Lipke, P. N. (1990). Isolation and characterization of cell surface mutants of Candida albicans. Infect Immun 58, 1552-1557.

Received 20 March 1997; revised 4 June 1997; accepted 10 June 1997. 